\title{
IN-WORK POVERTY IN LATVIA
}

\author{
Mareks Niklass ${ }^{1}$
}

\begin{abstract}
The results of a survey carried out in Latvia in 2015 are examined to estimate the scope and depth of in-work poverty. The widely used EU-SILC data considerably underestimate in-work poverty in Latvia. Logistic regression analysis indicates that persons with low education, poor health, persons of pre-retirement age, and those employed in non-standard work arrangements are more likely exposed to a high in-work poverty risk. Social transfers and the income of other household members do not significantly reduce this risk. The Latvian government should provide adequate social protection and funding to alleviate the in-work poverty problem.
\end{abstract}

UDC Classification: 316.4 , DOI: $10.12955 /$ cbup.v7.1414

Keywords: in-work poverty, Latvia, EU-SILC

\section{Introduction}

Latvia experienced a deep economic crisis in the period from 2008 to 2010. It had one of the largest GDP per capita drops in the EU reaching -12.9\% in 2009 (EU-28=-4.6\%) (Eurostat, 2017). It also brought mass unemployment averaging 19.5\% in 2010 (EU-28=8.3\%) (Eurostat, 2017). Since then, the Latvian economy has recovered. In 2018, the GDP per capita growth rate was $5.6 \%$ (Eurostat, $2019 \mathrm{~b}$ ) and the unemployment rate dropped to $7.4 \%$ (Eurostat, 2019c). However, these developments in Latvia have had a negligible effect on the in-work poverty rate, an indicator measuring poverty levels among the employed. In 2009 , the in-work poverty rate peaked at $11.2 \%$ but decreased only slightly to $8.2 \%$ in 2018 (Eurostat, 2019a). This contradiction is the main focus of this paper. The present study seeks to uncover why in-work poverty seems to persist in Latvia, evaluate current poverty indicators, and examine what alternative measurements could be used to assess in-work poverty. First, the paper evaluates a number of studies on in-work poverty in Europe. Second, the data derived from a large-scale survey are analyzed to estimate in-work poverty levels in Latvia. Finally, the paper compares various empirical sources and discusses a number of policy implications.

\section{Research background}

As various research studies (Hallerod et al. 2015; Horemans and Marx 2013; Lewandowski and Kaminska 2014; Giesselmann 2015; Marx et al. 2011; McKnight et al. 2016) show, in-work poverty is persistent over time and across many countries irrespective of their level of economic development and the generosity of their welfare programs. These studies show that there are several factors accounting for in-work poverty, which have been identified repeatedly.

Hallerod et al. (2015) analyze an EU-SILC longitudinal dataset from 2007 and 2008, to determine the causes of in-work poverty in twenty-two European countries with different welfare regimes. They conclude that the self-employed and those moving in and out of employment for various reasons are more likely to be affected by in-work poverty. They argue that in-work poverty is essentially an unemployment problem, not a low-wage problem (Hallerod et al. 2015).

Horemans and Marx (2013) analyze the 2011 EU-SILC data sets from fifteen member states (EU-15) to examine the link between part-time work and poverty. Their analysis shows that part-timers are more often at risk of poverty than full-time employees. They see a correlation between the incidences of involuntary part time work and poverty risk. The same holds true for those working part-time and caring for other family members. The latter problem mostly affects women (Horemans and Marx 2013). Horemans and Marx use the example of the Netherlands which has low in-work poverty rates. They note that there are "institutional and policy factors conducive to part-time" in place, i.e. child care facilities, supportive family policies and general understanding on the part of social partners (also employers) that part-time work is decent work (Horemans and Marx 2013).

Lewandowski and Kaminska (2014) provide a very detailed account of in-work poverty in Poland. They analyze the Poland Household Budget Survey data from 1998 to 2012. Although the employed are less likely to be poor than the unemployed, there is considerable risk of in-work poverty among those employed in the agricultural sector. Individuals with low educational achievement and temporary work contracts are also more likely to be at risk of poverty. They conclude that government policies have not sufficiently addressed in-work poverty (Lewandowski and Kaminska 2014).

\footnotetext{
${ }^{1}$ University of Latvia, Riga, Latvia, mareks.niklass@lu.lv
} 
Government policies should encourage individuals employed in the agricultural sector to move to other economic sectors. Low paid jobs should be taxed at a lower rate by increasing tax deductions. Family allowances should be increased, but paid work must pay off at the same time to avoid the low wage trap. The Government should encourage women to seek work to promote the development of more double earner households, which are less likely to become poor (Lewandowski and Kaminska 2014).

Giesselmann (2015) analyzes the German Socio-Economic Panel (SOEP) and British Household Panel Survey (BHPS) data gathered in 2002-2006 which estimate in-work poverty rates across different sociodemographic and occupational groups in each country. He identifies the trend of "a precarisation of entry-level positions in Germany and of older employees in the UK" (Giesselman 2015). In Germany, both entrants and re-entrants have a considerable risk of in-work poverty. It seems that entry level jobs more often offer atypical employment conditions in Germany. Entrants are more likely to be exposed to deregulation and marginalization. They are often left out of collective agreements and "closed employment relationships" (Giesselmann 2015). In Britain, Giesselmann sees a link between the openness of the employment system and increased poverty risks for older employees. Finally, he points out that the higher levels of education decrease in-work poverty risk, although the link is less pronounced in Britain. (Giesselmann 2015).

Marx et al. look (2011) at in-work poverty in Belgium. They analyze the relevant EU-SILC data set (obtained in 2006) and use the microsimulation model MISIM "to evaluate policy alternatives in the field of social security and personal income taxation (Marx et al. 2011). They found that individuals with lower education levels have a higher in-work poverty risk. It also holds true for young people, part-timers, employed lone parents, and single-earner couples with dependent children (Marx et al. 2011). The microsimulation suggests that substantial increases in minimum wages may not be sufficient to reduce in-work poverty in Belgium (Marx et al. 2011). Such a policy should be coupled with "reduced social security contributions and well-targeted individual tax credits" to the working poor (Marx et al. 2011). Finally, they acknowledge that there is a fundamental problem with most policy measures. Most measures proposed and analyzed so far are targeted at individuals (the low paid), not households with insufficient earnings. There are very few, if any, policies and measures that would encourage dual earnership and "the employment of carers" (Marx et al. 2011, p.22). They believe that universal child benefits should constitute "a key component of any effective policy package to tackle in-work poverty" (Marx et al. 2011).

McKnight et al. (2016) in their review sum up the evidence from multiple studies on in-work poverty and examine various measures to tackle the problem in the EU. They conclude that low paid workers, part-timers, those on temporary contracts, lone parents, and caregivers are more exposed to in-work poverty risk than other groups in society. The combination and overlap of those characteristics may worsen their situation even more (McKnight et al. 2016). Structural factors also play a role and contribute to cross-country variations. First, the labour market structure in each country may affect the prevalence of low paid and low skill jobs or the predominance of one or another sector where these jobs are found. Second, household composition and female employment varies greatly across the EU. In this regard, single parent families (mostly led by women) with temporary contracts and part-time work arrangements may have a greater poverty risk. Third, social and tax policies may or may not support families with children. Countries with adequate family support programs (tax deductions, kindergartens, allowances) have lower in-work poverty rates (McKnight et al. 2016).

To sum up, these studies suggest that labour market arrangements and individual career trajectories in various countries differ so much that it is difficult to detect common trends and provide a coherent explanation as to why in-work poverty persists in Europe. Nevertheless, it seems that non-standard employment and low pay do correlate with the incidence of in-work poverty in many countries.

\section{Data and methodology}

A survey carried out by the Advanced Social and Political Research Institute at the University of Latvia in 2015, is a source of empirical data for the following analysis of in-work poverty in Latvia. The survey sample is representative of the Latvian population aged 15 to 74 . The original sample included 2007 respondents. For this analysis of in-work poverty, 1,246 respondents were selected who met two criteria. They were 1) employed at the time of the survey and 2) were 15 to 64 years old. 
The survey was aimed at measuring poverty levels and associated contextual factors in Latvia. The survey questionnaire included a number of items intended to measure material deprivation in its various manifestations (ability to pay utility bills, afford durables, organize birthday parties, meet the relatives, pay for goods and services related to childcare and healthcare etc.). The questionnaire employed relevant poverty indicators also used in EU-SILC surveys.

Monetary indicators gathered from surveys are highly unreliable in estimating in-work poverty rates and identifying underlying causes because of the unwillingness of many respondents in Latvia to indicate their income levels and sources of revenue. A recent report by Foreign Investors' Council in Latvia (2016) suggests that the shadow economy comprised 21.3\% of the GDP in Latvia in 2015. The two main components of the shadow economy are the underreporting of business income and cash wage payments, the so-called envelope wages. The problem is more acute in the construction sector (Foreign Investors' Council in Latvia 2016). The latter is also supported by a report of State Labour Inspectorate (Valsts darba inspekcija) (2015), which indicates that $25 \%$ of incidents of unreported employment have been identified in construction companies. Unreported employment is also common in the agricultural and forestry sectors, as well as in the hospitality industry and small-scale retail companies, i.e. the sectors with a considerable share of low paid employees, which in turn are more likely to be exposed to in-work poverty risk.

Therefore, it is reasonable and more reliable to use other indicators to measure in-work poverty. Material deprivation and severe material deprivation rates are much more relevant indicators in the Latvian context. Underreporting and the unwillingness of many respondents to indicate their consumption and ability to pay, for example, utility bills are very rare. The author uses both items adopted by the Social Protection Committee (Eurostat, 2016) and two questions related to health care expenditures (ability to pay for health care treatment prescribed by a doctor or the ability to pay for prescription drugs) to calculate the material and severe material deprivation rates. The author argues that it is important to also include responses related to the use of health care services because health care expenditures constitute a large share of peoples' house hold budgets expenses in Latvia. Out-ofpocket payments for health care are more common than in other countries. In 2015, the share of outof-pocket expenditure reached $41.62 \%$ of the total health expenditure in Latvia (EU-28=15.31\%) (World Bank, 2019). Health care is very expensive, especially for the low paid. In short, the inability to pay healthcare bills must be taken as an essential component of any poverty measurement in Latvia.

\section{Results}

In-work poverty rates as calculated by Eurostat considerably underestimate the share of the poor among the working population. Material and severe material deprivation rates are better indicators of the incidence of poverty because they (as indicators) are less dependent on wage levels and tax rates (as well changes in those levels and rates). These indicators are more comparable across various countries and time periods. Eurostat's definition of material deprivation is outdated (possession of a TV set and a telephone is not a good indicator of poverty in the twenty-first century) and inadequate for contexts like Latvia, where many people need to pay for health care treatment out-of-pocket. If one considers the latter, the deprivation rate, as shown in Table 1, is higher than reported by Eurostat. The severe material deprivation as calculated by the author would be 13.6 percent and the material deprivation rate would be 25.7 percent.

\begin{tabular}{|l|c|c|}
\hline Table 1. Share of materially and severely materially deprived in the working age population (\%). \\
\hline & Material deprivation rate & $\begin{array}{c}\text { Severe material } \\
\text { deprivation rate }\end{array}$ \\
\hline $\begin{array}{l}\text { As defined by Social protection committee (at least } \\
\text { three out of nine items) }\end{array}$ & 21.9 & 11.1 \\
\hline $\begin{array}{l}\text { Author's calculations (items defined by Social } \\
\text { protection committee + items related to health care } \\
\text { expenditures, in total three items and more) }\end{array}$ & 25.7 & 13.6 \\
\hline N=1246 (population aged 15-64) & & \\
\hline Source: Author
\end{tabular}

Who is more likely to be affected by material deprivation in the working population in Latvia? Logistic regression analysis indicates that older employees, men, those with lower education levels, 
part-timers, and individuals with severe illness or disability are more likely to be poor (see Table 2). In the Latvian context, it should be noted that material deprivation also affects those living in the Riga metropolitan area. The latter is hard to explain because the questionnaire lacks items on the context and specificity of jobs (occupation, industry etc.). The research results largely support the conclusions of other researchers, for example, Horemans and Marx (2013) and Lewandowski and Kaminska (2014). Older, poorly skilled employees, and part-timers are severely affected by material deprivation. It is important to stress, that in the Latvian context, education is a good predictor of income. In 2014, when the Central Statistical Bureau conducted a detailed survey on wage levels and structure, it found that average gross monthly earnings for individuals with the first level of tertiary education (bachelor degrees) were 1133 EUR, whereas those with primary education earned 635 EUR (Central Statistical Bureau of Latvia, 2019). However, there are some important notes to make. It appears that the working poor live in poor households. The income of other family members does not reduce the incidence of material deprivation. Social transfers have no impact on the material deprivation of the working population in Latvia as well. It does support the conclusions by OECD that Latvia allocates very little to social security (OECD, 2016). Furthermore, factors like the presence of minors in the household and ethnic origin (a proxy variable "language spoken at home") does not increase the risk of material deprivation as indicated in other studies (McKnight et al. 2016).

\begin{tabular}{|c|c|c|c|}
\hline Groups & Odds ratios & Groups & Odds ratios \\
\hline Constant & $.028 * * *$ & Education & \\
\hline Age & & basic & $7.61 * * *$ \\
\hline $15-24$ (ref.) & ** & secondary & $4.72 * * *$ \\
\hline $25-34$ & $\mathrm{~ns}$ & vocational secondary & $3.09 * * *$ \\
\hline $35-44$ & $2.3 * *$ & incomplete higher/higher (ref.) & $* * *$ \\
\hline $45-54$ & $2.21 * *$ & Full time/part time & \\
\hline $55-64$ & $2.73 * *$ & part time & $1.96^{* * *}$ \\
\hline Sex & & Permanent/terminated contract & \\
\hline men & $1.37 *$ & permanent & ns \\
\hline Language spoken at home & & Have additional job/ no additional job & \\
\hline Latvian & $\mathrm{ns}$ & no additional job & $\mathrm{ns}$ \\
\hline Minors at home & & Have severe illness or disability & \\
\hline no minors & ns & severe illness or disability & $1.8^{*}$ \\
\hline Region & & Income of other family members & \\
\hline Riga - capital (ref.) & ** & no income & ns \\
\hline Riga metropolitan area & $1.82 * *$ & Social transfers (benefits, allowances) & \\
\hline Other regions & $\mathrm{ns}$ & no transfers & $\mathrm{ns}$ \\
\hline Classification accuracy & $76.8 \%$ & & \\
\hline Hosmer and Lemeshow Test (sig.) & .296 & & \\
\hline Nagelkerke R Square & .199 & & \\
\hline \multirow{2}{*}{\multicolumn{4}{|c|}{$\begin{array}{l}\text { Notes } \\
\mathrm{n}=1212 \text { (employed, aged } 15-64) \\
\text { Cases with Cook's distance values }>=1 \text { (influential cases) and standardized residual values }>=3 \text { (outliers) } \\
\text { were not included } \\
*^{\mathrm{p}}<0.05, * * \mathrm{p}<0.01, * * * \mathrm{p}<0.001, \mathrm{~ns}-\text { not significant }\end{array}$}} \\
\hline Source: Author & & & \\
\hline
\end{tabular}

In-work poverty is likely to persist in Latvia for a number of reasons. The labour market favours those with already good skills, education and better career positions at respective organizations. As logistic regression analysis show (see Table 3), those individuals with incomplete or higher education, with permanent job contracts and with no additional job are more likely to have been involved in some kind of in-work or occupation related training in the last twelve months. Education level and a permanent job contract are good proxy variables for one's income. The skill gap will widen and lower educational groups will find it difficult to catch up and progress in their careers. Large numbers of the working poor are likely to remain stuck in certain labour market segments with limited opportunities for career advancement and wage increase. 
It should be noted that there are two predictors that account for participation rates in occupational training, the language spoken at home and regional location. There is a large Russian speaking segment of the population in Latvia with poor Latvian language skills which limits their employment prospects in some sectors like retail and other service industries. Another obstacle is the structure of the educational system. State subsidized vocational and higher educational institutions, as well as many short courses provided by the State Employment Agency are almost always provided in Latvian. Thus, individuals with poor Latvian skills are less likely to consider or to be offered learning opportunities. Region as a predictor is harder to explain because there are no detailed questions why and in what kind of occupation related training individuals are involved. One might speculate that it relates to labour market volatility in each region. Riga as a capital city offers many opportunities for career advancement and job change but its labour market is highly volatile (high labour turnover rate), therefore, employers are reluctant to invest in their employees. The mobility and volatility argument is supported by a study conducted by two economists from the Bank of Latvia, which indicates that "two thirds of internal mobility took place within Riga and Pierīga" (Braukša and Fadejeva, 2013), i.e. in two of the most economically developed regions in Latvia.

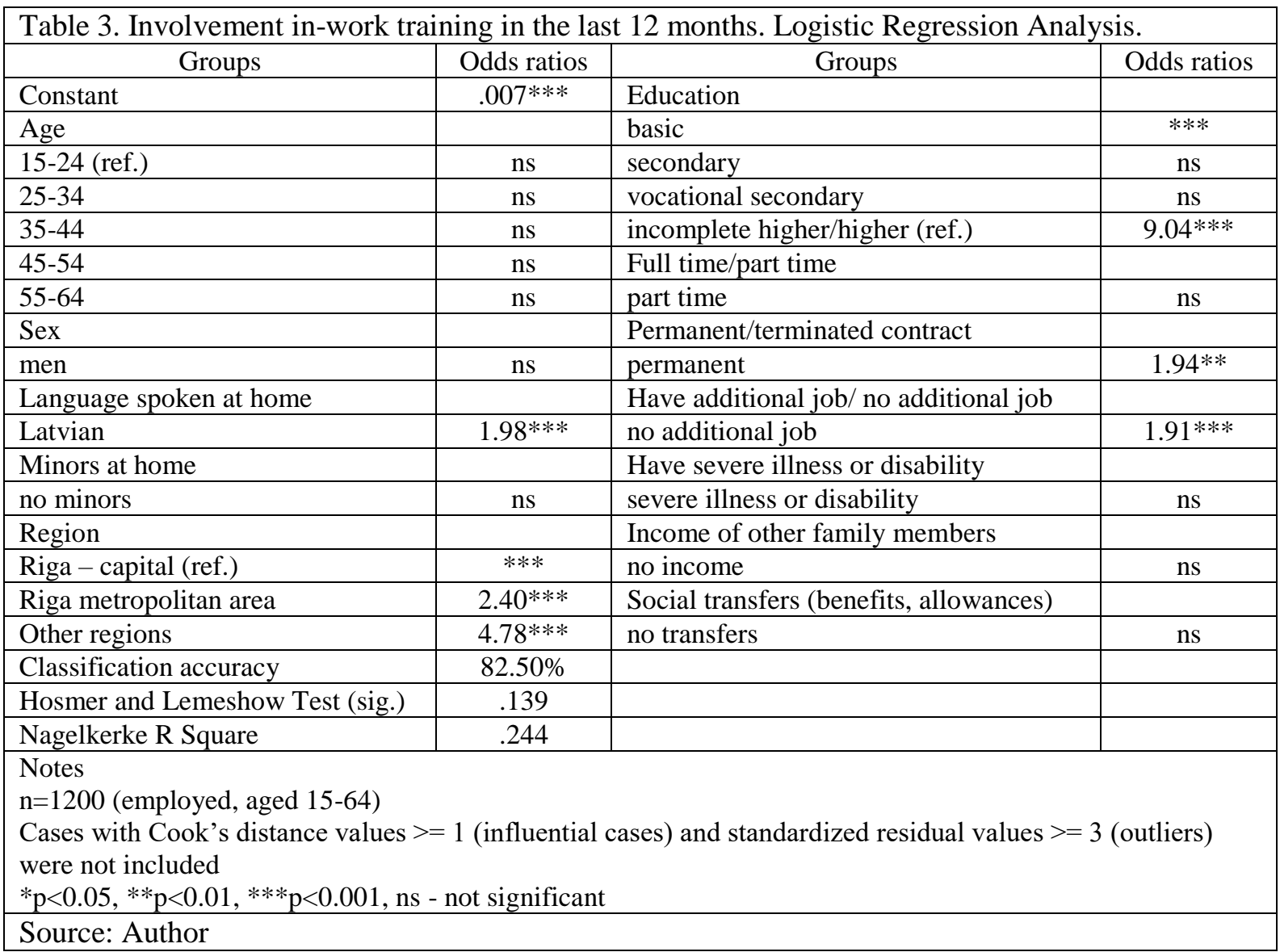

\section{Discussion}

Although this study used a different approach in measuring in-work poverty, the results of the analysis do correlate with the conclusions of some of the scholars discussed above. Horemans and Marx (2013) argue that part-timers are more likely to be exposed to poverty risk. Atypical employment conditions are also mentioned as risk factors in Germany (see Giesselmann 2015).

In the Latvian context, education is a good predictor of in-work poverty incidence. Those with low education achievement levels have a significantly higher risk of material deprivation. Available statistics on income suggest that low education strongly correlates with low incomes in Latvia (Central Statistical Bureau of Latvia 2019). Similar results have been drawn from studies in Poland and Belgium (see Lewandowski and Kaminska 2014; McKnight et al., 2016). As the Latvian survey data analyzed in this paper indicates, the skills gap is likely to widen because there are few opportunities for the low skilled to acquire the necessary human capital to claim higher wages in the future. 
This study indicates that those of pre-retirement age in Latvia are also at a considerable in-work poverty risk. Unfortunately, the survey questionnaire did not include questions on the working environments of various social groups. Very few studies suggest that the elderly are more likely to be exposed to in-poverty risk in Europe. Giesselmann's study indicates that it is so in Great Britain, which he explains is due to the openness of the employment system there (Giesselmann 2015). It may be interpreted in other words as a more deregulated labour market. Although this study does not examine labour market regulations, it is safe to describe the Latvian labour market as less regulated. It has few redundancy rules as indicated by a recent report by the World Bank (World Bank 2017).

This study also supports the conclusions of a number of studies (See Marx et al. 2011; McKnight at al., 2016) that part-timers are susceptible to in-work poverty risk. Because of the limitations in the questionnaire, specific questions about part-time work were not included (involuntary/voluntary, work-life balance etc.). The sample size included too few part-timers to draw any meaningful conclusions. In regard to temporary workers, lone parents, and caregivers, the present study does not confirm the conclusions of other studies (McKnight et al., 2016). Again, the most plausible explanation might be a limited sample size, which did not include adequate numbers of individuals drawn from the above groups.

Two important observations emerge from this study, which are not in accord with the results of other studies. Social transfers (allowances, benefits) and the incomes of other family members do not significantly reduce the risk of material deprivation in the working population. Two factors may account for that. First, Latvia spends very little on social welfare. As a result, social funding has a negligible effect on the working poor. Second, the materially deprived people are likely to live in poor households and the presence of other earning adults does not have a significant effect. The author agrees with the recommendations of the World Bank and OECD that lifting the tax burden and providing adequate social protection for the poor and low-paid workers should be one of the priorities of Latvian government in the near future (World Bank 28.01.2016.; OECD, 2016).

\section{Conclusion}

In this article, the author argues that in-work poverty rates calculated by Eurostat underestimate the share of the working poor exposed to poverty risk. Material and severe material deprivation rates are more reliable measures because they are broadly comparable across various countries and time periods. In the Latvian context, it is important to note that medical bills are a great concern for many people. Out-of-pocket payments for health care are one of the largest in Europe. Unfortunately, the items related to health care expenditures are not included in Eurostat's calculations of material deprivation, thus the current measurements underestimate the poverty level in Latvia.

The author uses the data from a large-scale survey to measure in-work poverty. He includes data on health care expenditures in his measurement of the material deprivation rate. He estimates that onequarter of the working population (aged 15-64) is materially deprived. One-seventh of all employees can be considered severely materially deprived.

In-work poverty is essentially a problem of the poorly skilled and low paid in Latvia. There are, though, some important caveats. A combination of factors like illness and disability, pre-retirement age and part-time work may increase the poverty risk for some individuals. It seems that some men (among the low skilled and paid) have considerable difficulties earning a living. In-work poverty is likely to persist for a number of reasons. The working poor are concentrated mostly in what social scientists call precarious jobs with limited opportunities for advancement. These jobs do not offer inwork training and security. Thus, the skill gap between upper level professionals and the low skilled is likely to widen and the latter group is less likely to advance in their respective jobs.

Other factors such as social policies may also play a role. Latvia contributes very little to social security. Out-of-pocket payments are commonplace and the share of such payments is very high. Health care services are very often inaccessible for many poor people. Their health may deteriorate and their labour market positions may increasingly worsen. If government and society as a whole do not address the above problems, in-work poverty and poverty in general will likely persist in Latvia.

\section{Acknowledgment}

The work was supported by Latvian State Research Program "Sustinno". 


\section{References}

Braukša, I. \& Fadejeva, L. (2013). Internal Labour Market Mobility in 2005-2011: The Case of Latvia.” Latvijas Banka Working Paper, No. 2/2013. Retrieved from https://www.bank.lv/images/stories/pielikumi/publikacijas/petijumi/Brauksa_Fadejeva_Labour_mobility_in_Latvia.pdf Central Statistical Bureau of Latvia. (2019). DSS3.2. Average gross monthly earnings by occupations and level of education in the year euro. Retrieved http://data.csb.gov.lv/pxweb/en/sociala/sociala_dsamaksa_strukt_dsamaksa_strukt_2014/DSS142.2.px/table/tableViewLayout1/

Eurostat. (2016). Glossary: Material deprivation. Retrieved from http://ec.europa.eu/eurostat/statisticsexplained/index.php/Glossary:Material_deprivation

Eurostat. (2017). Real GDP per capita, growth rate and totals. Percentage change on previous year, EUR per inhabitant. Retrieved from http://ec.europa.eu/eurostat/web/products-datasets/-/tsdec100

Eurostat. (2019a). In-work at-risk-of-poverty rate by age and sex - EU-SILC survey [ilc_iw01]. Retrieved from http://ec.europa.eu/eurostat/web/products-datasets/-/ilc_iw01

Eurostat. (2019b). Real GDP per capita. Chain linked volumes, percentage change on previous period, per capita. Retrieved from https://ec.europa.eu/eurostat/web/products-datasets/product?code=tec00115

Eurostat. (2019c). Unemployment by sex and age - annual average. Retrieved from http://appsso.eurostat.ec.europa.eu/nui/show.do?dataset=une_rt_a\&lang=en

Foreign Investors' Council in Latvia. (2016). Foreign investors' viewpoint on the Shadow Economy in Latvia. Retrieved from http://www.ficil.lv/f/Shadow_Economy_May\%2025_FINAL.pdf

Giesselmann, M. (2015). Differences in the Patterns of in-work Poverty in Germany and the UK. European Societies 171: 27-46. http://doi.org/10.1080/14616696.2014.968796

Halleröd, B., Ekbrand, H., \& Bengtsson, M. (2015). In-work poverty and labour market trajectories: Poverty risks among the working population in 22 European countries. Journal of European Social Policy 255: 473-488. http://doi.org/10.1177/0958928715608794

Horemans, J. \& Marx, I. (2013). In-work poverty in times of crisis: do part-timers fare worse?, ImPRovE Discussion Paper No. 13/14. Retrieved from http://www.centrumvoorsociaalbeleid.be/ImPRovE/Working\%20Papers/ImPRovE\%20WP\%201314_1.pdf

Lewandowski, P. \& Kaminska, A. (2014). In-work poverty in Poland. Diagnosis and possible remedies. Retrieved from http://ibs.org.pl/app/uploads/2015/01/In-Work-Poverty-in-Poland_Diagnosis-and-Possible-Remedies.pdf

Marx, I., Vanhille, J. \& Verbist, G. (2011). Combating In-Work Poverty in Continental Europe: An Investigation Using the Belgian Case. IZA Discussion Paper No. 6067. Retrieved from http://anon-ftp.iza.org/dp6067.pdf

McKnight, A., Stewart, K., Himmelweit, S.M. \& Palillo, M. (2016). Low pay and in-work poverty: preventative measures and preventative approaches. Retrieved from

http://ec.europa.eu/social/main.jsp?catId=738\&langId=en\&pubId=7901\&furtherPubs=yes

OECD. (2016). OECD Reviews of Labour Market and Social Policies: Latvia 2016. OECD Publishing, Paris. DOI: http://dx.doi.org/10.1787/9789264250505-en

Valsts Darba Inspekcija (State Labour Inspectorate). (2016). 2015.gada darbības pārskats. Izgūts no http://www.vdi.gov.lv/files/vdi_gada_parskats_2015.pdf [in Latvian]

World Bank. (2017). Doing Business 2017: Equal Opportunity for All. Latvia. Washington, DC: World Bank. DOI: $10.1596 / 978-1-4648-0948$

World Bank. (2019). Health Nutrition and Population Statistics. World Data Bank. Retrieved from http://databank.worldbank.org/data/reports.aspx?source=health-nutrition-and-population-statistics

World Bank. (28.01.2016.) World Bank to Evaluate Equity and Efficiency of the Latvian Tax System. Retrieved from http://www.worldbank.org/en/news/press-release/2016/01/28/world-bank-to-evaluate-equity-and-efficiency-of-latvian-taxsystem 